\title{
Vascular heterogeneity and targeting: the role of YKL-40 in glioblastoma vascularization
}

\author{
Rong Shao ${ }^{1,2}$, Sherry L. Taylor ${ }^{3}$, Dennis S. Oh ${ }^{4}$ and Lawrence M. Schwartz ${ }^{1,2}$ \\ ${ }^{1}$ Department of Biology, University of Massachusetts, Amherst, MA, USA \\ ${ }^{2}$ Molecular and Cellular Biology Program, Morrill Science Center, University of Massachusetts, Amherst, MA, USA \\ ${ }^{3}$ Department of Neurosurgery, Tufts University, Boston, MA, USA \\ ${ }^{4}$ Department of Surgery, Baystate Medical Center, Tufts University, Springfield, MA, USA \\ Correspondence to: Rong Shao, email: Rshao@umass.edu
}

Lawrence M. Schwartz, email: schwartz@bio.umass.edu

Keywords: glioblastoma, YKL-40, glioblastoma stem-like cells, transdifferentiation, tumor angiogenesis

Received: July 22, $2015 \quad$ Accepted: September 14, $2015 \quad$ Published: October 01, 2015

This is an open-access article distributed under the terms of the Creative Commons Attribution License, which permits unrestricted use, distribution, and reproduction in any medium, provided the original author and source are credited.

\section{ABSTRACT}

Malignant glioblastomas (GBM) are highly malignant brain tumors that have extensive and aberrant tumor vasculature, including multiple types of vessels. This review focuses on recent discoveries that the angiogenic factor YKL-40 (CHI3L1) acts on glioblastoma-stem like cells (GSCs) to drive the formation of two major forms of tumor vascularization: angiogenesis and vasculogenic mimicry (VM). GSCs possess multipotent cells able to transdifferentiate into vascular pericytes or smooth muscle cells (PC/SMCs) that either coordinate with endothelial cells (ECs) to facilitate angiogenesis or assemble in the absence of ECs to form blood-perfused channels via VM. GBMs express high levels of YKL-40 that drives the divergent signaling cascades to mediate the formation of these distinct microvascular circulations. Although a variety of anti-tumor agents that target angiogenesis have demonstrated transient benefits for patients, they often fail to restrict tumor growth, which underscores the need for additional therapeutic tools. We propose that targeting YKL-40 may compliment conventional anti-angiogenic therapies to provide a substantial clinical benefit to patients with GBM and several other types of solid tumors.

\section{INTRODUCTION}

Glioblastoma (GBM), a grade IV glioma, is the most lethal primary brain tumor in human with a median survival of around 3 months without treatment and 1215 months with therapeutic interventions [1-2]. Even with extensive surgical excision and post-operative adjuvant radio/chemotherapy, approximately half of patients relapse, and fewer than $3 \%$ of cancer patients survive longer than 5 years [3-4]. Although GBMs rarely spread outside the central nervous system, they typically present as extensive infiltrating tumors with the ability to vigorously invade adjacent normal brain tissue, thereby precluding curative surgical removal. GBM is characterized by strong vascular proliferation that is associated with tumor cell growth, invasion, resistance to chemo/radiotherapy, and decreased disease-free survival
[5-6]. Hence understanding the molecular mechanisms that mediate vascular development and pathogenesis is of paramount importance in clinical practice for patients who receive anti-angiogenic drug therapy.

A number of distinct vascular phenotypes in GBM have been identified in which tumor angiogenesis is one of the most prominent forms of vascularization [7-8]. Tumor angiogenesis is a vessel-sprouting process characterized by the migration and proliferation of pre-existing vascular endothelial cells (ECs) followed by the recruitment of pericytes or smooth muscle cells (PC/SMCs) that support vessel stability and enable blood perfusion [9]. Some of the pre-existing vessels are also able to split and give rise to secondary daughter vessels, a vascular event known as intussusception [8]. Vessel co-option also occurs in some cases, whereby tumor cells drive or hijack pre-existing vessels in order to develop new vascular networks [10- 
11]. Over the past a few years, another major form of tumor vascularization has been discovered in GBM in which tumor cells assemble to vascular channels, independent of endothelial cells [12-13]. Such tumor cellmediated vascular formation lacking ECs is referred to as vasculogenic mimicry (VM) [14].

Over the past decade, the secreted glycoprotein YKL-40, also named chitinase 3-like 1 (Chi311) [15-18], has emerged as a potential mediator of GBM progression. YKL-40 is a highly conserved $40-\mathrm{kDa}$ chitin- or heparinbinding glycoprotein, which places it into the family of chitinase-like proteins. However, YKL-40 lacks chitinase/ hydrolase activity because of a mutation in the chitinase3-like catalytic domain that converts an essential glutamic acid into leucine residue. Gene expression profiling has demonstrated that YKL-40 is ranked as one of the most dramatically induced genes in GBM [19-20]. A wealth of clinical evidence has also revealed that elevated serum levels of YKL-40 in GBM are positively correlated with cancer invasiveness, radioresistance, recurrence, and reduced patient survival times [19-25]. In concert with these findings, radiotherapy-resistant GBMs express elevated levels of YKL-40, which may at least partially contribute to the tumor malignancy $[21,26]$. The roles and molecular mechanisms that mediate YKL-40-dependent vascularization of GBM have been the subject of several recent studies. We have found that YKL-40 acts as an angiogenic factor to promote tumor angiogenesis in both GBM and breast cancer [27-28]. This review focuses primarily on the recently identified roles of YKL-40 in facilitating both angiogenesis and VM in GBM, with a focus on current therapeutic limitations evident in the treatment of patients with conventional anti-angiogenic drugs.

\section{TUMOR ANGIOGENESIS}

\subsection{Endothelial cells}

Tumor angiogenesis is a pathologic process that is primarily mediated by the growth and sprouting of vascular ECs [29-30]. These ECs typically develop from vascular lineage differentiation of bone marrowderived CD34+-hematopoietic stem cells. Other cell types can also participate in tumor angiogenesis, including endothelial progenitor cells (EPCs) and cancer stem celldifferentiated vascular cells [31-33]. While the majority of glioblastoma stem-like cells (GSCs) commit to neural lineage differentiation including glial cells or astrocytes, neurons, and oligodendrocytes, a small percentage of GSCs display the ability to transdifferentiate into ECs [31, 34-36]. However, the molecular mechanisms underlying the vascular transdifferentiation of GSCs are still poorly understood and its potential clinical importance for tumor vascularization and malignance in patients with GBM has yet to be fully determined.

While there is a substantial body of research characterizing the role of angiogenic factors like vascular endothelial cell growth factor (VEGF) in facilitating vascularization of GBM (see multiple excellent review articles [3, 37-38]), it has been demonstrated recently that YKL-40 also plays pivotal roles in GBM [27]. YKL-40 is a potent angiogenic factor that is able to induce endothelial cell angiogenesis. Recombinant YKL-40 can promote tube formation and migration of cultured ECs with the same angiogenic potential as VEGF, one of the most potent angiogenic factors yet identified [28, 39]. In addition, YKL-40 induces both VEGF expression in a GBMderived cell line U87 and VEGF receptor 2 (VEGFR 2) expression in ECs (Figure 1) [27, 40]. Consequently, all of these angiogenic molecules may collaborate synergistically to trigger tumor angiogenesis. Interestingly, inhibition of VEGF led to the induction of YKL-40 in U87 cells $[25,27]$, suggesting potential compensatory effects among multiple angiogenic factors in order to sustain vessel formation. RNAi-mediated gene knockdown of YKL-40 expression in U87 cells significantly inhibited tumor angiogenesis in xenografted animal models, as EC-lined vessel density of YKL-40 shRNA tumors was decreased to $44 \%$ of control tumor vessels [28]. In line with these findings, treating U87 tumor-bearing mice with a neutralizing anti-YKL-40 antibody (mAY) resulted in abrogation of tumor angiogenesis, reduced distant metastasis, and increased mouse survival [27, 40], all of which underscore an angiogenic signature of YKL-40 in tumor progression. In a small set of patients with GBM, tumor expression of YKL-40 was correlated with increased EC-associated vessel density and VEGF expression, and decreased patient survival [27], which agrees well with the data in pre-clinical studies. All of these data support the hypothesis that YKL-40 acts as a potent angiogenic factor to stimulate angiogenesis in GBM. It is intriguing to speculate that combined anti-angiogenic therapies targeting both YKL-40 and VEGF might dramatically reduce tumor angiogenesis and block tumor progression.

One candidate "receptor" that may transduce YKL-40-mediated angiogenic activity in ECs is the membrane-bound protein syndecan-1, an abundant cellular surface heparan sulfate (Figure 1) [28, 39]. Given its inherent heparin-binding property, YKL-40 was found to bind to heparan sulfate chains of syndecan-1 on cell surface and facilitate the coupling of syndecan-1 with an adjacent membrane-associated protein integrin $\alpha v \beta 3$, thus activating angiogenic responses through $\mathrm{FAK}^{861}$ to MAP kinase ERK 1 and 2 in ECs [28]. VEGFR 2 induced by YKL-40 could sensitize ECs to VEGF, resulting in enhanced angiogenesis. Likewise, YKL-40 could induce VEGF expression in U87 cells by means of the similar signaling pathway (Figure 1) [27]. For example, YKL40 stimulates the association of syndecan-1 with integrin 
$\alpha v \beta 5$, which leads to downstream activation of $\mathrm{FAK}^{397}$ and ERK 1 and 2, thereby augmenting VEGF gene expression, which in turn cooperates with YKL-40 to activate ECs and elicit angiogenesis (Figure 1). In addition, YKL-40 has the ability to activate $\mathrm{PI}_{3} \mathrm{~K}-\mathrm{AKT}$ pathways in U87 cells, which then inhibits cell death induced by $\gamma$-irradiation $[27,40]$. These mechanistic insights support the hypothesis that YKL-40 functions as both a potent angiogenic factor and a growth factor that serves to promote a number of downstream signaling cascades in both ECs and tumor cells. Jack Elias' group recently identified a YKL-40binding receptor, IL-13R $\alpha 2$, which is expressed by macrophages responsible for bacterial killing [41]. Both
YKL-40 and IL-13R $\alpha 2$ were also found to mediate melanoma lung metastasis [42]. In GBM, the expression of IL-13R $\alpha 2$ was significantly elevated, but it has not been determined yet if IL-13R $\alpha 2$ functions to mediate YKL-40induced angiogenesis (Figure 1) [43-44]. It is noted that IL-13R $\alpha 2$ also serves as a decoy receptor for IL-13 that regulates apoptosis. Hsi et al. found that knockdown of the IL-13R $\alpha 2$ gene in GBM cells promoted IL-13-dependent cell death and restricted tumor growth [45]. Therefore, it would be valuable to determine if IL-13R $\alpha 2$ acts as a core factor to control the dual axes of YKL-40/IL-13R $\alpha 2$ and IL-13/IL-13R $\alpha 2$ in tumor malignancy.

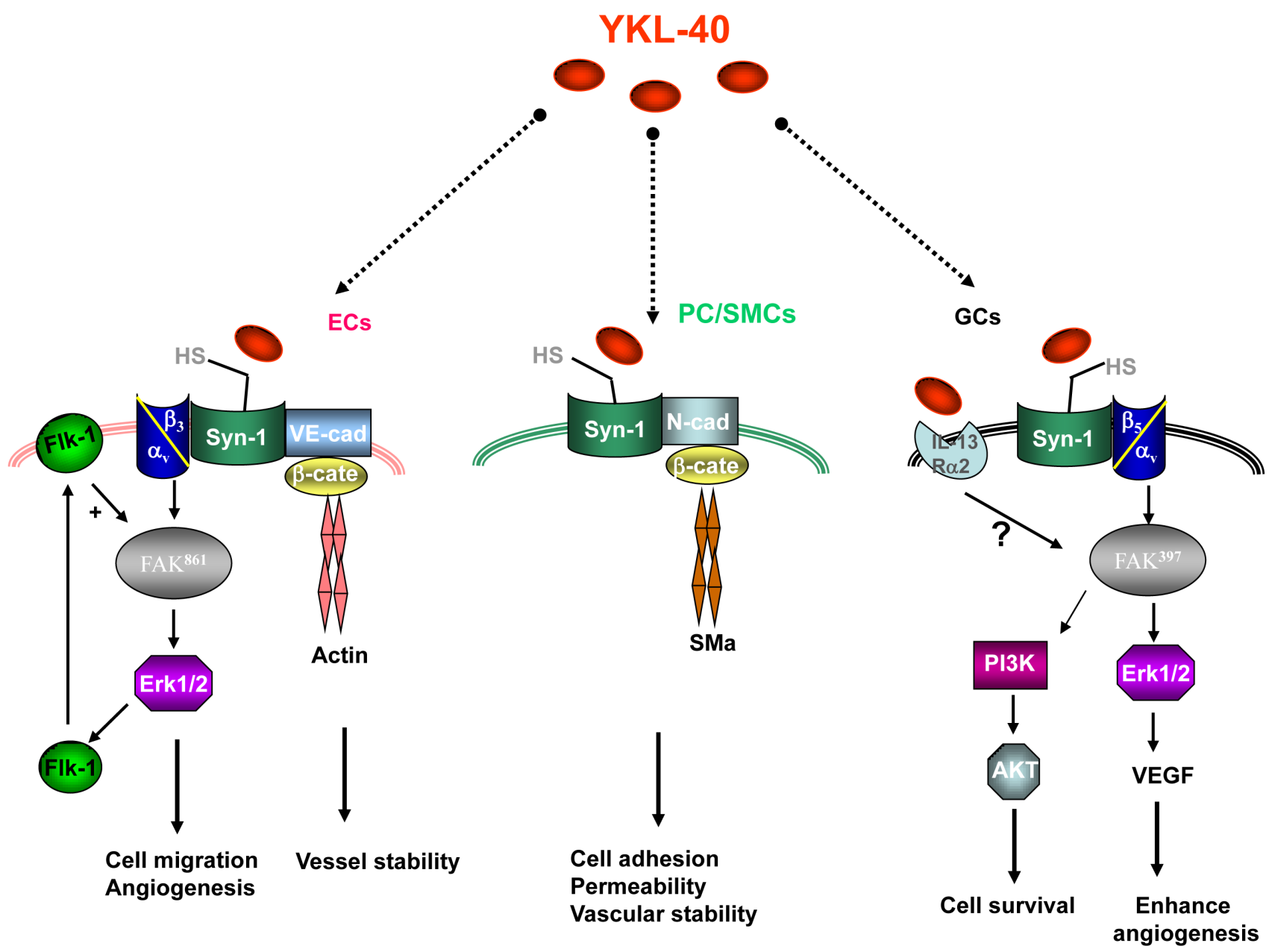

Figure 1: YKL-40 induces multiple signaling pathways in endothelial cells (ECs), pericytes/smooth muscle cells (PC/SMCs), and glioblastoma cells (GCs). YKL-40 activates interaction of syndecan-1 (Syn-1) and integrin $\alpha v \beta 3$, which leads to intracellular signaling via FAK ${ }^{861}$ and ERK 1/2 [28], and several tumor-promoting processes that include the expression of VEGFR 2 (Flk-1), enhanced cell motility, and EC-mediated angiogenesis [40]. YKL-40-induced Flk-1 activation enhances angiogenic responses. YKL-40 may prompt coupling of Syn- 1 with vascular cadherin (VE-cad), which then recruits $\beta$-catenin ( $\beta$-cate) and cytoskeleton protein actin, thereby facilitating vessel stability [60]. YKL-40 can also induce the association of Syn-1 with N-cadherin (N-cad) and intracellular $\beta$-cate and downstream smooth muscle alpha actin (SMa) in PC/SMCs, which leads to increased cell adhesion, enhanced permeability, and vascular stability $[60,63]$. Identical to angiogenic signaling in ECs, YKL-40 stimulates coordination of Syn-1 and integrin $\alpha v \beta 5$, downstream effectors FAK ${ }^{397}$ and ERK 1/2, which induces the expression of VEGF in glioblastoma cells (GCs) [27]. In addition, YKL-40 augments signaling cascades PI3K-AKT, which in turn protects GCs from $\gamma$-irradiation-induced apoptosis. Intracellular signaling pathways for YKL-40-binding receptor IL-13R $\alpha 2$ in GCs need to be established. HS: heparan sulfate chains that bind to YKL-40. 
Table 1: Anti-vascular agents used in clinical trials of GBM

\begin{tabular}{|l|l|l|}
\hline Name & Molecular targets & Action mechanisms \\
\hline Aflibercept (VEGF trap) & VEGF-A; VEGF-B, PIGF & Decoy receptor \\
\hline AMG102 & HGF & Anti-HGF antibody \\
\hline Bevacizumab & VEGF-A & Anti-VEGF antibody \\
\hline Brivanib & FGFR, VEGFR2 & Receptor tyrosine kinase inhibitor \\
\hline Cediranib (AZD2171) & VEGFR1-3, PDGFR $\beta$, c-kit & Receptor tyrosine kinase inhibitor \\
\hline Cilengitide & Integrin $\alpha$ v3/ $\alpha$ v $\beta 5$ & Short peptides binding integrins \\
\hline CT-322 & VEGFR1-3 & Adnectin \\
\hline Dasatinib & PDGFR $\beta$, Src, BCR-Abl, c-kit, ephrin & Receptor tyrosine kinase inhibitor \\
\hline Erlotinib & A2 & Receptor tyrosine kinase inhibitor \\
\hline Gefitinib & EGFR & Receptor tyrosine kinase inhibitor \\
\hline Imatinib & EGFR & Receptor tyrosine kinase inhibitor \\
\hline Pazopanib & PDGFR $\beta$, BCR-Abl, c-kit, & Receptor tyrosine kinase inhibitor \\
\hline Sorafenib & VEGFR1-3, c-kit, PDGFR $\alpha / \beta$ & Receptor tyrosine kinase inhibitor \\
\hline Sunitinib & VEGFR2, 3, c-kit, PDGFR $\beta$, Raf & Receptor tyrosine kinase inhibitor \\
\hline Tandutinib & VEGFR2, 3, c-kit, PDGFR $\beta$, FLT3 & Receptor tyrosine kinase inhibitor \\
\hline Vandetanib (ZD6474) & PDGFR $\beta$, FLT3, c-kit & Receptor tyrosine kinase inhibitor \\
\hline Vatalanib & VEGFR2, EGFR & Receptor tyrosine kinase inhibitor \\
\hline XL-184 & VEGFR1-3, c-kit, PDGFR $\alpha / \beta$ & Receptor tyrosine kinase inhibitor \\
\hline
\end{tabular}

\subsection{Pericytes/smooth muscle cells}

Once endothelial cells have transformed into vascular tubes, mesenchyme-derived mural cells, referred to as pericytes/smooth muscle cells (PC/ $\mathrm{SMCs}$ ), are recruited to the out layer of the neovessels [46]. The recruitment of PC/SMCs in turn enhances EC proliferation, survival, migration, differentiation, and vascular branching [47-48]. This reciprocal activation is accomplished by the interaction and activation between angiogenic molecules secreted from ECs and their corresponding binding receptors expressed by PC/SMCs, such as angiopoietin-1/Tie-2 [49-50] and platelet-derived growth factor-B (PDGF-B)/PDGF receptor- $\beta$ (PDGFR- $\beta$ ) [51-53], all of which enable longitudinal spreading of $\mathrm{PC} / \mathrm{SMCs}$ along EC-based growing vessels. In GBM, it is also notable that $\mathrm{PC} / \mathrm{SMCs}$ play a pivotal role in the vessel development, as multiple agents targeting PDGF-B/ PDGFR- $\beta$ signaling have been utilized in pre-clinical and clinical trials to inhibition of tumor angiogenesis. However, targeting PDGF could also impair vessel stability and integrity, leading to blood diffusion into the tissue. For example, multiple clinical trials with imatinib that blocks kinase activity of PDGFR and c-kit, have given rise to severe complications that are commonly associated with tumor hemorrhage in young patients with neuroblastoma, GBM and gastrointestinal stromal tumors [54-57] (see following Sections $4.1 \& 4.2$ ).

Recently, VEGF was shown to function as a "permeability factor" that impairs PC/SMC-associated vascular integrity. Ablation of myeloid cell-derived VEGF in mice led to increased vessel coverage of $\mathrm{PC} /$
SMCs and acceleration of tumorigenesis [58-59]. It would be valuable to determine if this VEGF-inhibited vessel stability depends on PC/SMC expression of VEGFR 1 or 2. In contrast to VEGF, YKL-40 maintains vascular stability and integrity [60]. YKL-40 is expressed by PC/ SMCs and serves as a mesenchymal cell marker [6162]. YKL-40 can promote the association of syndecan-1 with neural cadherin in the cell membrane, which in turn recruits both $\beta$-catenin and cytoskeleton protein smooth muscle actin (SMa), further facilitating inter-PC/SMC adhesion (Figure 1). In addition, YKL-40 induces the same coordination of vascular cadherin and $\beta$-catenin on ECs, which also contributes to vascular permeability and stability (Figure 1) [60]. Blockade of YKL-40 by either gene knockdown or the use of mAY decreases vessel coverage by $\mathrm{PC} / \mathrm{SMCs}$ and results in increased vascular permeability and leakage, thus leading to vessel collapse and dysfunction in brain tumor xenografts [60]. Furthermore, combination therapy with $\mathrm{mAY}$ and ionizing irradiation synergistically inhibited PC/SMC-mediated tumor angiogenesis [63]. Collectively, these data suggest that YKL-40 acts comparably in PC/SMCs and ECs in ways that govern vascular stability and integrity in GBM. Supporting this hypothesis, a pilot study of ten patients with GBM has revealed a strong correlation between YKL-40 expression on PC/SMCs and tumor vascular stability, permeability and decreased patient survival [60].

\section{VASCULOGENIC MIMICRY}

Separate from the EC-associated angiogenesis, a number of independent studies suggest that VM 
Table 2: Anti-vascular agents used in glioblastoma xenografts

\begin{tabular}{|l|l|l|}
\hline Name & Action mechanisms & References \\
\hline Bevacizumab & Anti-VEGF antibody & {$[83],[115]$} \\
\hline Cediranib & VEGFR tyrosine kinase inhibitor & {$[87]$} \\
\hline DC101 & Anti-VEGFR2 antibody & {$[88],[90],[116]$} \\
\hline SU10944 & VEGFR2 tyrosine kinase inhibitor & {$[116]$} \\
\hline SU5416 & VEGFR2 tyrosine kinase inhibitor & {$[89]$} \\
\hline SU6668 & PDGFR tyrosine kinase inhibitor & {$[89]$} \\
\hline Sunitinib & VEGFR2 tyrosine kinase inhibitor & {$[116]$} \\
\hline
\end{tabular}

also contributes to GBM vascularization [64]. This agrees well with the observation that VM is a common microvascular circulation in other cancers such as melanoma, colorectal cancer, and breast cancer [65-67]. VM-associated vasculature can represent up to $50 \%$ of total vessel content in some cases of GBM [68]. These vascular-like channels can be formed independently of ECs via transdifferentiation of GSCs into PC/SMCs [69-70]. Although the individual contributions of subpopulation of $\mathrm{CD}_{133^{+}}$and CD133- GSCs into VM are still controversial [71-72], a significant population ( $20 \%$ ) of general GSCs derived from patients with GBM were able to transdifferentiate into PC/SMCs that could participate in both VM and angiogenesis (Figure 2) [12, 68]. GBM-derived PC/SMCs developed VM that lack ECs and exhibited a leaky vascular phenotype [60]. In contrast, in the presence of ECs these GSC-differentiated $\mathrm{PC} / \mathrm{SMCs}$ can interact intimately with ECs to facilitate angiogenesis and produce vessels that are more stable and had the ability to perfuse tumors more efficiently (Figure 2) [60]. In additional to YKL-40, VEGFR2 was also found to mediate the transdifferentiation of GSCs into PC/SMC and control VM. For instance, VEGFR2 gene knockdown or treatment with a VEGFR2 kinase inhibitor (SU1498) impeded GSC transdifferentiation and subsequent VM in xenograft models and in cultured cells [73-74]. It is noteworthy that VEGFR2-mediated $\mathrm{PC} / \mathrm{SMC}$ transdifferentiation is independent of VEGF, in contrast with the transdifferentiation of GSCs into ECs which is dependent on VEGF [8, 75-76]. This finding may account, at least partially, for the observation that some recurrent cases of GBM are unresponsive to VEGFdirected drugs such as bevacizumab (see discussion below). Consequently, substantial data support the notion that VEGFR2, like YKL-40, may be an appropriate target for the treatment of GBM.

\section{ANTI-VASCULAR THERAPIES IN GBM}

\subsection{Anti-angiogenic therapy}

Many of the drugs that are used in clinical trials for GBM are designed to inhibit EC and/or PC/SMC receptor tyrosine kinases with the goal of disrupting tumor vasculature (Table 1). For example, FDA approved drugs for the treatment of recurrent GBM, including small molecule inhibitors of the VEGFR kinase and antiVEGF antibodies like bevacizumab, target the VEGF pathways (Table 1). As reviewed in a number of previous publications, most of clinical trials exploiting these agents have provided encouraging results such as increased progression-free survival in patients (Table 1) [3, 77-80]. Accordingly, multiple research labs have also employed some of these drugs, or related compounds, in orthotopic xenografted animal models in order to validate these clinical findings (Table 2) [81-83]. Despite the promising evidence documented in the literature, the overall benefits of these treatments for patients with GBM are moderate and transient, as high mortality of the disease remains static.

\subsection{Vessel normalization}

Pre-clinical and clinical studies have established a new therapeutic paradigm that is complementary to the conventional vessel-blocking regimens, in which normalization of tumor vascular abnormalities impedes tumor development [84-85]. Instead of a complete blockade of tumor vessel formation, some of antiangiogenic therapies, including VEGFR kinase inhibitors cediranib and SU5416, an anti-VEGFR antibody DC101, and a PDGFR kinase inhibitor SU6668, ameliorate vascular normalization and alleviate peritumoral edema in GBMs and other cancers (Table 1 \& 2) [86-90]. PC/ SMCs act as the primary cells that support vessel function and blood perfusion. Consequently, depletion of $\mathrm{PC} /$ SMCs in animal tumor models diminished aberrant blood vessel formation, increased tumor hypoxia, and ultimately restrained tumor growth [9]. In agreement with these animal studies, over-expression of PDGF in patient-derived tumors was found to be associated with enhanced cancer malignancy [91], while blockade of PDGF signaling resulted in improvement of drug delivery and chemotherapy $[47,92]$. It should be noted that codelivery of two different drugs targeting ECs (e.g. VEGFR inhibitor) and PC/SMCs (e.g. PDGFR $\beta$ inhibitor) was more effective in inhibiting tumor development than individual anti-angiogenic drugs, presumably because they enhanced the destabilization of vessels by inhibiting PC/ 
SMC function, thus rendering ECs more susceptible to EC blockers [93-94]. In spite of these encouraging findings, conflicting evidence has also been reported from several animal studies and clinical trials. For instance, deletion of $\mathrm{PC} / \mathrm{SMCs}$ promotes tumor progression, possibly due to lack of a barrier that prevents tumor cells from dissemination into the circulatory system [95]. Consistent with these findings, decreased PC/SMC coverage around vessels in patients with colorectal cancer is correlated with enhanced cancer metastasis [96]. Although the molecular mechanisms underlying these unfavorable outcomes remain to be elucidated, they do suggest that multiple regulatory pathways are likely involved in the formation and maintenance of tumor vascular network that depends on spatial-temporal interaction between ECs and $\mathrm{PC} /$ SMCs. In addition, treating GBM patients with imatinib in order to target PDGFR-mediated vessel stability could lead to intra-tumoral bleeding, a severe side effect observed frequently in the anti-vascular therapy [54, 57, 97]. Therefore, the multiple factors that control these cell activities and influence vessel coverage, permeability and stability, oxygen delivery, and blood perfusion should be circumspectly considered in evaluating drug delivery and therapy.

\subsection{An unexpected therapeutic outcome -- angiogenic rebound}

Multiple independent clinical trials evaluating bevacizumab have demonstrated patient benefits for a number of different cancers, which led to FDA approval of bevacizumab as a first-line treatment for brain tumors [82, 98-100], breast cancers [101], colorectal cancers [102], and non-small-cell lung cancers [103-104]. However, several recent clinical investigations with large patient cohorts suggest that the use of this antiangiogenic therapy for advanced tumors are controversial and the ultimate benefits are still inconclusive [81, 105113]. For example, a long-term therapeutic intervention with bevacizumab in GBMs only produced a transitory benefit, with no significantly prolonged overall survival. Once the therapy was terminated, the tumors underwent vascular recovery and regrew rapidly. In concert with these clinical observations, GBM xenografts in mice treated with bevacizumab or DC101 displayed reduced tumor blood supply, but unexpectedly, increased tumor cell invasion [114-116]. In addition, treatment with sunitinib, DC101 and other VEGFR inhibitors (AG013736 and AG-028262) in other animal tumor studies led to revascularization, increased tumor cell invasiveness,

\section{Angiogenesis}
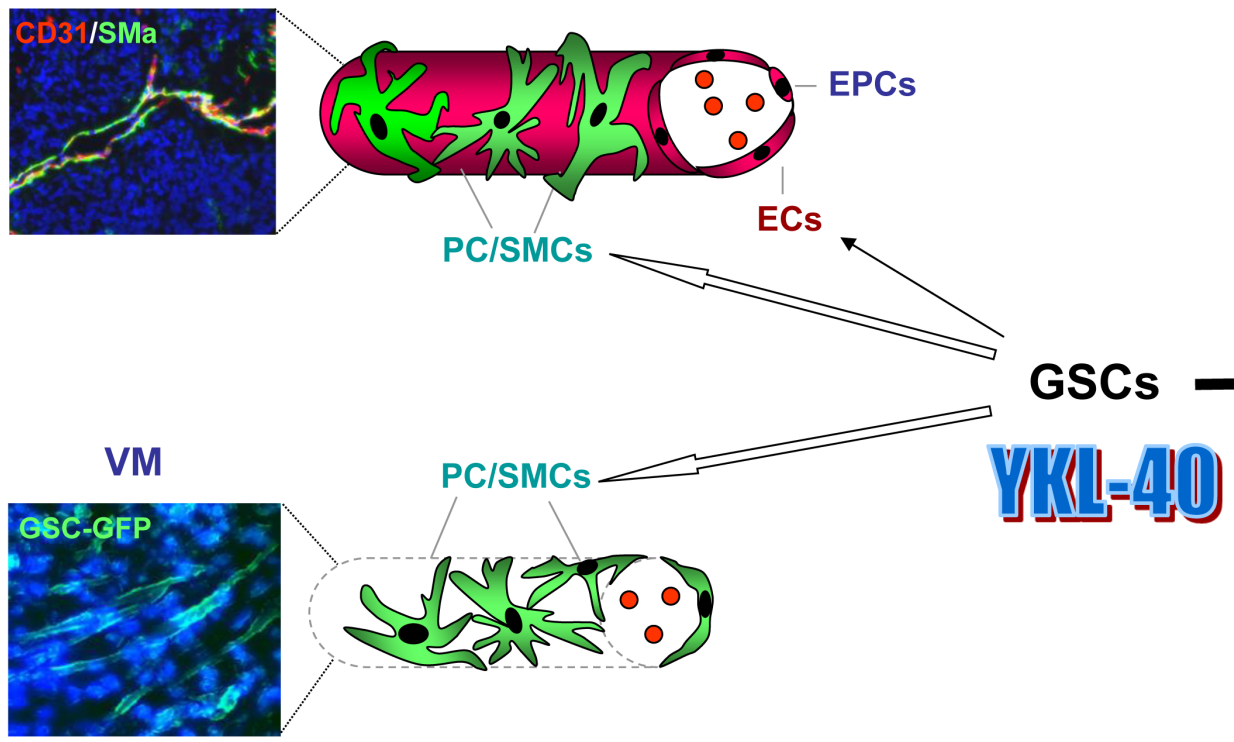

GC

Figure 2: A model for YKL-40-mediated tumor vascularization that is associated with vascular transdifferentiation of GSCs in GBM. YKL-40 expressed and secreted by glioblastoma cells (GCs) is associated with tumor vascularization and malignancy of GBM, in which a large population of GCs is derived from a hierarchy of glioblastoma stem-like cells (GSC). GSCs can transdifferentiate into vascular pericytes/smooth muscle cells (PC/SMCs) that support endothelial cell (EC)-based vessel integrity in angiogenesis and as well as assemble into vascular channels in the absence of ECs, a process known as vasculogenic mimicry (VM). In addition, a small population of GSCs also displays the ability to transdifferentiate into ECs that can participate in angiogenesis. In some cases, endothelial progenitor cells (EPCs) cooperate with ECs to develop tumor vessels. Co-immunofluorescence staining shows ECs and PC/SMCs that are specifically recognized by anti-CD31 (red) and smooth muscle actin alpha (SMa) (green) antibodies, respectively. Autofluorescence of GSCs expressing green fluorescent protein (GFP) displays vascular channels in VM. YKL-40 ( $\diamond)$ and blood cells $(\bigcirc)$. 
and distant metastasis [116-118]. This rapidly acquired adaptation to anti-angiogenic therapies is recognized to be associated with the angiogenic switch whereby treated tumors undergo robust revascularization and malignant transformation $[117,119]$. In addition to the contribution by EC-derived new vessel formation in angiogenic resistance, alternative vascular networks like VM should not be neglected, since tumor-derived vascular channels likely offer a new blood-perfused microcirculatory system. Indeed, PC/SMC-derived vascular channels during VM are resistant to bevacizumab in xenografts $[8,75]$. Therefore, it might be quite interesting to determine if tumor cells or tumor-derived PC/SMCs act as the predominant vascular cells to orchestrate neovasculature including vascular channel formation via VM in patients that are resistant to angiogenic drugs. Although the molecular mechanisms underlying this drug resistance remain to be clarified, multifaceted therapies targeting both ECs and PC/SMCs might offer a significant clinical benefit.

\section{CHALLENGES AND FINAL REMARKS}

Robust vascular proliferation is one of the hallmarks of GBM, in which tumor angiogenesis is commonly recognized as the primary component of tumor vessels. Interestingly, growing evidence suggests that tumor cellassociated vascular channels lacking ECs represent a significant portion of the tumor vasculature in some cases of GBM. Indeed, a simplistic vasculature model merely focusing on EC-mediated angiogenesis is insufficient to describe the range of sophisticated neovascular networks in which tumor cells and bone marrow-derived cells (e.g. EPCs, myelomonocytes) also participate in neovascularization [120-122]. In addition to GSC-derived tumor cells, it would be worthy to determine what other cell types also contribute to VM. A growing literature suggests that tumor cell-derived vascular channels represent at least one of the alternative microvascular systems that are independent of EC-associated angiogenesis and that they represent an alternative vascular supply when traditional anti-angiogenic drugs fail in therapy [13, 123-124]. A number of individual research groups have demonstrated that GSCs can transdifferentiate into PC/SMCs and ECs, both of which mediate tumor vascularization [31, 68, 125]. However, many of the details of the underlying cellular and molecular pathways that mediate this transdifferentiation in vivo remain to be defined. In particular, we still lack sufficient knowledge of if and how GSC-derived PC/SMCs cooperate with host mesenchyme-derived PC/SMCs to contribute to angiogenesis and VM. Are the former cells more active than the latter during tumor vascularization? If so, do VEGFR, YKL-40, or other factors render these cells more aggressive? Why do GSCs preferentially transdifferentiate into PC/SMCs rather than ECs? What are the core factors that commit GSCs to these individual differentiations into varied types of vascular cells? Understanding these key regulatory processes may help facilitate the identification of new therapeutic targets for cancer treatment, especially for patients that are refractory to anti-EC-directed angiogenic drugs. It is also worth noting that continuously monitoring the dynamic changes in the circulating levels of YKL-40 in patients that receive some of antiangiogenic drugs might help predict unfavorable outcomes of the disease, and trigger the utilization of alternative therapeutic strategies.

A number of well control studies have reported that bevacizumab fails to yield therapeutic efficacy in blocking tumor vascularization or increasing patient survival. Consequently, identifying the key factors that promote VEGF-independent tumor vascularization is of paramount importance for treatment of recurrent patients that resist bevacizumab. Elevated serum levels of YKL-40 in GBM patients are positively correlated with tumor invasiveness, resistance to chemo/radiotherapy, and short survival, suggesting that YKL-40 serves as a prognostic biomarker for poorer clinical outcomes. YKL40 stimulates tumor vascularization via EC and PC/SMCcoordinated angiogenesis and PC/SMC-driven VM, thus pointing to YKL-40 as a new target for cancer therapy. A number of independent methods to target YKL-40 activity (e.g. YKL-40 shRNA and mAY) have provided constant therapeutic promise in both in vitro and in vivo studies [39]. Specifically, the anti-vascular efficacy of $\mathrm{mAY}$ in animal xenografts suggests a new and exciting therapeutic avenue whereby a humanized anti-YKL-40 antibody could offer a substantial benefit for the treatment of several cancers, resulting in an enhanced quality of life for patients. Anti-YKL-40 therapy may also sensitize tumors to anti-VEGF/VEGFR treatment in relapsing patients that demonstrate resistance to anti-VEGF/VEGFR drugs. In addition, targeting YKL-40 receptor IL-13R $\alpha 2$ is also anticipated to serve as a potent alternative strategy for either blocking YKL-40-induced tumor vascularization or eliciting a synergetic effect in conjunction with $\mathrm{mAY}$. While a significant population of patients with recurring GBM are resistant to anti-angiogenic drugs, an alternative strategy with combined therapies targeting YKL-40 and other angiogenic factors might represent a significant advance for treatment.

\section{Abbreviations}

GBM: glioblastoma; YKL-40: human cartilage glycoprotein-39 or chitinase-3-like-1; mAY: a neutralizing anti-YKL-40 antibody; ECs: endothelial cells; PC/SMCs: pericytes or smooth muscle cells; GSCs: glioblastomastem like cells, VM: vasculogenic mimicry; EPCs: endothelial progenitor cells; VEGF: vascular endothelial cell growth factor; VEGFR: vascular endothelial cell growth factor receptor; PDGF-B: platelet-derived growth factor-B; PDGFR- $\beta$ : PDGF receptor- $\beta$. 


\section{CONFLICTS OF INTEREST}

No potential conflicts of interest were disclosed.

\section{REFERENCES}

1. Wen PY, Kesari S. Malignant gliomas in adults. N Engl J Med. 2008;359:492-507.

2. van den Bent MJ, Bromberg JE. Neuro-oncology: The many challenges of treating elderly glioblastoma patients. Nat Rev Neurol. 2015;11:374-375.

3. Norden AD, Drappatz J, Wen PY. Antiangiogenic therapies for high-grade glioma. Nat Rev Neurosci. 2009;5:610-620.

4. Reardon DA, Wen PY. Glioma in 2014: Unravelling tumour heterogeneity-implications for therapy. Nat Rev Clin Oncol. 2015;12:69-70.

5. Gilbertson RJ, Rich JN. Making a tumour's bed: Glioblastoma stem cells and the vascular niche. Nat Rev Cancer. 2007;7:733-736.

6. Furnari FB, Cloughesy TF, Cavenee WK, Mischel PS. Heterogeneity of epidermal growth factor receptor signalling networks in glioblastoma. Nat Rev Cancer. 2015; 15:302-310.

7. Carmeliet P, Jain RK. Molecular mechanisms and clinical applications of angiogenesis. Nature. 2011;473:298-307.

8. Takano S. Glioblastoma angiogenesis: Vegf resistance solutions and new strategies based on molecular mechanisms of tumor vessel formation. Brain Tumor Pathol. 2012;29:73-86.

9. Huang FJ, You WK, Bonaldo P, Seyfried TN, Pasquale EB, Stallcup WB. Pericyte deficiencies lead to aberrant tumor vascularizaton in the brain of the ng2 null mouse. Dev Biol. 2010;344:1035-1046.

10. Zagzag D, Amirnovin R, Greco MA, Yee H, Holash J, Wiegand SJ, Zabski S, Yancopoulos GD, Grumet M. Vascular apoptosis and involution in gliomas precede neovascularization: A novel concept for glioma growth and angiogenesis. Lab Invest. 2000;80:837-849.

11. Brat DJ, Van Meir EG. Vaso-occlusive and prothrombotic mechanisms associated with tumor hypoxia, necrosis, and accelerated growth in glioblastoma. Lab Invest. 2004;84:397-405.

12. El Hallani S, Boisselier B, Peglion F, Rousseau A, Colin C, Idbaih A, Marie Y, Mokhtari K, Thomas JL, Eichmann A, Delattre JY, Maniotis AJ, Sanson M. A new alternative mechanism in glioblastoma vascularization: Tubular vasculogenic mimicry. Brain. 2010;133:973-982.

13. Chen Y, Jing Z, Luo C, Zhuang M, Xia J, Chen Z, Wang Y. Vasculogenic mimicry-potential target for glioblastoma therapy: An in vitro and in vivo study. Med Oncol. 2012;29:324-331.

14. Maniotis AJ, Folberg R, Hess A, Seftor EA, Gardner LM, Pe'er J, Trent JM, Meltzer PS, Hendrix MJ. Vascular channel formation by human melanoma cells in vivo and in vitro: Vasculogenic mimicry. Am J Path. 1999;155:739752 .

15. Hakala BE, White C, Recklies AD. Human cartilage gp39, a major secretory product of articular chondrocytes and synovial cells, is a mammalian member of a chitinase protein family. J Biol Chem. 1993;268:25803-25810.

16. Nyirkos P, Golds EE. Human synovial cells secrete a 39 kda protein similar to a bovine mammary protein expressed during the non-lactating period. Biochem J. 1990;269:265268.

17. Rejman JJ, Hurley WL. Isolation and characterization of a novel 39 kilodalton whey protein from bovine mammary secretions collected during the nonlactating period. Biochem Biophys Res Commun. 1988;150:329-334.

18. Johansen JS, Williamson MK, Rice JS, Price PA. Identification of proteins secreted by human osteoblastic cells in culture. J Bone Miner Res. 1992;7:501-512.

19. Nigro JM, Misra A, Zhang L, Smirnov I, Colman H, Griffin C, Ozburn N, Chen M, Pan E, Koul D, Yung WK, Feuerstein BG, Aldape KD. Integrated array-comparative genomic hybridization and expression array profiles identify clinically relevant molecular subtypes of glioblastoma. Cancer Res. 2005;65:1678-1686.

20. Tanwar MK, Gilbert MR, Holland EC. Gene expression microarray analysis reveals ykl-40 to be a potential serum marker for malignant character in human glioma. Cancer Res. 2002;62:4364-4368.

21. Pelloski CE, Mahajan A, Maor M, Chang EL, Woo S, Gilbert M, Colman H, Yang H, Ledoux A, Blair H, Passe $\mathrm{S}$, Jenkins RB, Aldape KD. Ykl-40 expression is associated with poorer response to radiation and shorter overall survival in glioblastoma. Clin Cancer Res. 2005;11:33263334.

22. Nutt CL, Betensky RA, Brower MA, Batchelor TT, Louis DN, Stemmer-Rachamimov AO. Ykl-40 is a differential diagnostic marker for histologic subtypes of high-grade gliomas. Clin Cancer Res. 2005;11:2258-2264.

23. Hormigo A, Gu B, Karimi S, Riedel E, Panageas KS, Edgar MA, Tanwar MK, Rao JS, Fleisher M, DeAngelis LM, Holland EC. Ykl-40 and matrix metalloproteinase-9 as potential serum biomarkers for patients with high-grade gliomas. Clin Cancer Res. 2006;12:5698-5704.

24. Abe T, Okamura K, Ono M, Kohno K, Mori T, Hori S, Kuwano M. Induction of vascular endothelial tubular morphogenesis by human glioma cells. A model system for tumor angiogenesis. J Clin Invest. 1993;92:54-61.

25. Saidi A, Javerzat S, Bellahcene A, De Vos J, Bello L, Castronovo V, Deprez M, Loiseau H, Bikfalvi A, Hagedorn $\mathrm{M}$. Experimental anti-angiogenesis causes upregulation of genes associated with poor survival in glioblastoma. Int $\mathbf{J}$ Cancer. 2008;122:2187-2198.

26. Junker N, Johansen JS, Hansen LT, Lund EL, Kristjansen PE. Regulation of ykl-40 expression during genotoxic or microenvironmental stress in human glioblastoma cells. 
Cancer Sci. 2005;96:183-190.

27. Francescone RA, Scully S, Faibish M, Taylor SL, Oh D, Moral L, Yan W, Bentley B, Shao R. Role of ykl-40 in the angiogenesis, radioresistance, and progression of glioblastoma. J Biol Chem. 2011;286:15332-15343.

28. Shao R, Hamel K, Petersen L, Cao QJ, Arenas RB, Bigelow C, Bentley B, Yan W. Ykl-40, a secreted glycoprotein, promotes tumor angiogenesis. Oncogene. 2009;28:44564468.

29. Folkman J. Tumor angiogenesis: Therapeutic implications. N Engl J Med. 1971;285:1182-1186.

30. Hanahan D, Weinberg RA. Hallmarks of cancer: The next generation. Cell. 2011;144:646-674.

31. Wang R, Chadalavada K, Wilshire J, Kowalik U, Hovinga KE, Geber A, Fligelman B, Leversha M, Brennan C, Tabar V. Glioblastoma stem-like cells give rise to tumour endothelium. Nature. 2010;468:829-833.

32. Plummer PN, Freeman R, Taft RJ, Vider J, Sax M, Umer BA, Gao D, Johns C, Mattick JS, Wilton SD, Ferro V, McMillan NA, Swarbrick A, et al. Micrornas regulate tumor angiogenesis modulated by endothelial progenitor cells. Cancer Res. 2013;73:341-352.

33. Chang YS, di Tomaso E, McDonald DM, Jones R, Jain RK, Munn LL. Mosaic blood vessels in tumors: Frequency of cancer cells in contact with flowing blood. Proc Natl Acad Sci U S A. 2000;97:14608-14613.

34. Ricci-Vitiani L, Pallini R, Biffoni M, Todaro M, Invernici G, Cenci T, Maira G, Parati EA, Stassi G, Larocca LM, De Maria R. Tumour vascularization via endothelial differentiation of glioblastoma stem-like cells. Nature. 2010;468:824-828.

35. Soda Y, Marumoto T, Friedmann-Morvinski D, Soda M, Liu F, Michiue H, Pastorino S, Yang M, Hoffman RM, Kesari S, Verma IM. Transdifferentiation of glioblastoma cells into vascular endothelial cells. Proc Natl Acad Sci U S A. $2011 ; 108: 4274-4280$.

36. Lathia JD, Mack SC, Mulkearns-Hubert EE, Valentim CL, Rich JN. Cancer stem cells in glioblastoma. Genes Dev. 2015;29:1203-1217.

37. Carmeliet P. Angiogenesis in life, disease and medicine. Nature. 2005;438:932-936.

38. Jain RK. Molecular regulation of vessel maturation. Nat Med. 2003;9:685-693.

39. Shao R. Ykl-40 acts as an angiogenic factor to promote tumor angiogenesis. Front Physiol. 2013;4:122.

40. Faibish M, Francescone R, Bentley B, Yan W, Shao R. A ykl-40-neutralizing antibody blocks tumor angiogenesis and progression: A potential therapeutic agent in cancers. Mol Cancer Ther. 2011;10:742-751.

41. He CH, Lee CG, Dela Cruz CS, Lee CM, Zhou Y, Ahangari F, Ma B, Herzog EL, Rosenberg SA, Li Y, Nour AM, Parikh CR, Schmidt I, et al. Chitinase 3-like 1 regulates cellular and tissue responses via il-13 receptor alpha2. Cell Rep. 2013;4:830-841.
42. Ma B, Herzog EL, Lee CG, Peng X, Lee CM, Chen X, Rockwell S, Koo JS, Kluger H, Herbst RS, Sznol M, Elias JA. Role of chitinase 3-like-1 and semaphorin 7a in pulmonary melanoma metastasis. Cancer Res. 2015;75:487496.

43. Kasahara Y, Tuder RM, Taraseviciene-Stewart L, Le Cras TD, Abman S, Hirth PK, Waltenberger J, Voelkel NF. Inhibition of vegf receptors causes lung cell apoptosis and emphysema. J Clin Invest. 2000;106:1311-1319.

44. Saikali S, Avril T, Collet B, Hamlat A, Bansard JY, Drenou B, Guegan Y, Quillien V. Expression of nine tumour antigens in a series of human glioblastoma multiforme: Interest of egfrviii, il-13ralpha2, gp100 and trp-2 for immunotherapy. J Neurooncol. 2007;81:139-148.

45. Hsi LC, Kundu S, Palomo J, Xu B, Ficco R, Vogelbaum MA, Cathcart MK. Silencing il-13ralpha2 promotes glioblastoma cell death via endogenous signaling. Mol Cancer Ther. 2011;10:1149-1160.

46. Armulik A, Genove G, Betsholtz C. Pericytes: Developmental, physiological, and pathological perspectives, problems, and promises. Dev Cell. 2011;21:193-215.

47. Hellberg C, Ostman A, Heldin CH. Pdgf and vessel maturation. Recent Results Cancer Res. 2010;180:103-114.

48. Hellstrom M, Gerhardt H, Kalen M, Li X, Eriksson U, Wolburg H, Betsholtz C. Lack of pericytes leads to endothelial hyperplasia and abnormal vascular morphogenesis. J Cell Biol. 2001;153:543-553.

49. Suri C, Jones PF, Patan S, Bartunkova S, Maisonpierre PC, Davis S, Sato TN, Yancopoulos GD. Requisite role of angiopoietin-1, a ligand for the tie 2 receptor, during embryonic angiogenesis. Cell. 1996;87:1171-1180.

50. Vikkula M, Boon LM, Carraway KL, 3rd, Calvert JT, Diamonti AJ, Goumnerov B, Pasyk KA, Marchuk DA, Warman ML, Cantley LC, Mulliken JB, Olsen BR. Vascular dysmorphogenesis caused by an activating mutation in the receptor tyrosine kinase tie2. Cell. 1996;87:1181-1190.

51. Hellstrom M, Kalen M, Lindahl P, Abramsson A, Betsholtz C. Role of pdgf-b and pdgfr-beta in recruitment of vascular smooth muscle cells and pericytes during embryonic blood vessel formation in the mouse. Development. 1999; 126:3047-3055.

52. Lindahl P, Johansson BR, Leveen P, Betsholtz C. Pericyte loss and microaneurysm formation in pdgf-b-deficient mice. Science. 1997;277:242-245.

53. Abramsson A, Lindblom P, Betsholtz C. Endothelial and nonendothelial sources of pdgf-b regulate pericyte recruitment and influence vascular pattern formation in tumors. J Clin Invest. 2003;112:1142-1151.

54. Bond M, Bernstein ML, Pappo A, Schultz KR, Krailo M, Blaney SM, Adamson PC. A phase ii study of imatinib mesylate in children with refractory or relapsed solid tumors: A children's oncology group study. Pediatr Blood Cancer. 2008;50:254-258. 
55. Podtcheko A, Ohtsuru A, Tsuda S, Namba H, Saenko V, Nakashima M, Mitsutake N, Kanda S, Kurebayashi J, Yamashita S. The selective tyrosine kinase inhibitor, sti571, inhibits growth of anaplastic thyroid cancer cells. [see comment]. J Clin Endocrinol Metab. 2003;88:18891896.

56. Reardon DA, Desjardins A, Vredenburgh JJ, Sathornsumetee S, Rich JN, Quinn JA, Lagattuta TF, Egorin MJ, Gururangan S, McLendon R, Herndon JE, 2nd, Friedman AH, Salvado AJ, et al. Safety and pharmacokinetics of dose-intensive imatinib mesylate plus temozolomide: Phase 1 trial in adults with malignant glioma. Neuro Oncol. 2008;10:330-340.

57. Rutkowski P, Ruka W. Emergency surgery in the era of molecular treatment of solid tumours. Lancet Oncol. 2009; 10:157-163.

58. Greenberg JI, Shields DJ, Barillas SG, Acevedo LM, Murphy E, Huang J, Scheppke L, Stockmann C, Johnson RS, Angle N, Cheresh DA. A role for vegf as a negative regulator of pericyte function and vessel maturation. Nature. 2008;456:809-813.

59. Stockmann C, Doedens A, Weidemann A, Zhang N, Takeda N, Greenberg JI, Cheresh DA, Johnson RS. Deletion of vascular endothelial growth factor in myeloid cells accelerates tumorigenesis. Nature. 2008;456:814-818.

60. Francescone R, Ngernyuang N, Yan W, Bentley B, Shao R. Tumor-derived mural-like cells coordinate with endothelial cells: Role of ykl-40 in mural cell-mediated angiogenesis. Oncogene. 2014;33:2110-2122.

61. Phillips HS, Kharbanda S, Chen R, Forrest WF, Soriano RH, Wu TD, Misra A, Nigro JM, Colman H, Soroceanu L, Williams PM, Modrusan Z, Feuerstein BG, et al. Molecular subclasses of high-grade glioma predict prognosis, delineate a pattern of disease progression, and resemble stages in neurogenesis. Cancer Cell. 2006;9:157-173.

62. Ricci-Vitiani L, Pallini R, Larocca LM, Lombardi DG, Signore M, Pierconti F, Petrucci G, Montano N, Maira G, De Maria R. Mesenchymal differentiation of glioblastoma stem cells. Cell Death Differ. 2008;15:1491-1498.

63. Shao R, Francescone R, Ngernyuang N, Bentley B, Taylor SL, Moral L, Yan W. Anti-ykl-40 antibody and ionizing irradiation synergistically inhibit tumor vascularization and malignancy in glioblastoma. Carcinogenesis. 2014;35:373382.

64. Seftor RE, Hess AR, Seftor EA, Kirschmann DA, Hardy KM, Margaryan NV, Hendrix MJ. Tumor cell vasculogenic mimicry: From controversy to therapeutic promise. Am J Pathol. 2012;181:1115-1125.

65. di Tomaso E, Capen D, Haskell A, Hart J, Logie JJ, Jain RK, McDonald DM, Jones R, Munn LL. Mosaic tumor vessels: Cellular basis and ultrastructure of focal regions lacking endothelial cell markers. Cancer Res. 2005;65:5740-5749.

66. Hendrix MJ, Seftor EA, Hess AR, Seftor RE. Vasculogenic mimicry and tumour-cell plasticity: Lessons from melanoma. Nat Rev Cancer. 2003;3:411-421.

67. Shirakawa K, Kobayashi H, Heike Y, Kawamoto S, Brechbiel MW, Kasumi F, Iwanaga T, Konishi F, Terada $\mathrm{M}$, Wakasugi H. Hemodynamics in vasculogenic mimicry and angiogenesis of inflammatory breast cancer xenograft. Cancer Res. 2002;62:560-566.

68. Scully S, Francescone R, Faibish M, Bentley B, Taylor SL, Oh D, Schapiro R, Moral L, Yan W, Shao R. Transdifferentiation of glioblastoma stem-like cells into mural cells drives vasculogenic mimicry in glioblastomas. J Neurosci. 2012;32:12950-12960.

69. Mao XG, Xue XY, Wang L, Zhang X, Yan M, Tu YY, Lin W, Jiang XF, Ren HG, Zhang W, Song SJ. Cdh5 is specifically activated in glioblastoma stemlike cells and contributes to vasculogenic mimicry induced by hypoxia. Neuro Oncol. 2013;15:865-879.

70. Dong J, Zhao Y, Huang Q, Fei X, Diao Y, Shen Y, Xiao H, Zhang T, Lan Q, Gu X. Glioma stem/progenitor cells contribute to neovascularization via transdifferentiation. Stem Cell Rev. 2011;7:141-152.

71. Chiao MT, Yang YC, Cheng WY, Shen CC, Ko JL. Cd133+ glioblastoma stem-like cells induce vascular mimicry in vivo. Curr Neurovasc Res. 2011;8:210-219.

72. Ping YF, Bian XW. Consice review: Contribution of cancer stem cells to neovascularization. Stem Cells. 2011;29:888894.

73. Yao X, Ping Y, Liu Y, Chen K, Yoshimura T, Liu M, Gong W, Chen C, Niu Q, Guo D, Zhang X, Wang JM, Bian X. Vascular endothelial growth factor receptor 2 (vegfr-2) plays a key role in vasculogenic mimicry formation, neovascularization and tumor initiation by glioma stem-like cells. PLoS One. 2013;8:e57188.

74. Yao XH, Ping YF, Bian XW. Contribution of cancer stem cells to tumor vasculogenic mimicry. Protein Cell. 2011;2:266-272.

75. Francescone R, Scully S, Bentley B, Yan W, Taylor SL, Oh D, Moral L, Shao R. Glioblastoma-derived tumor cells induce vasculogenic mimicry through flk-1 protein activation. J Biol Chem. 2012;287:24821-24831.

76. Folkins C, Shaked Y, Man S, Tang T, Lee CR, Zhu Z, Hoffman RM, Kerbel RS. Glioma tumor stem-like cells promote tumor angiogenesis and vasculogenesis via vascular endothelial growth factor and stromal-derived factor 1. Cancer Res. 2009;69:7243-7251.

77. Meadows KL, Hurwitz HI. Anti-vegf therapies in the clinic. Cold Spring Harb Perspect Med. 2012;2

78. Agarwal S, Sane R, Oberoi R, Ohlfest JR, Elmquist WF. Delivery of molecularly targeted therapy to malignant glioma, a disease of the whole brain. Expert Rev Mol Med. 2011;13:e17.

79. Ellis LM, Hicklin DJ. Vegf-targeted therapy: Mechanisms of anti-tumour activity. Nat Rev Cancer. 2008;8:579-591.

80. Ferrara N, Kerbel RS. Angiogenesis as a therapeutic target. Nature. 2005;438:967-974. 
81. Kreisl TN, Kim L, Moore K, Duic P, Royce C, Stroud I, Garren N, Mackey M, Butman JA, Camphausen K, Park J, Albert PS, Fine HA. Phase ii trial of single-agent bevacizumab followed by bevacizumab plus irinotecan at tumor progression in recurrent glioblastoma. J Clin Oncol. 2009;27:740-745.

82. Nghiemphu PL, Liu W, Lee Y, Than T, Graham C, Lai A, Green RM, Pope WB, Liau LM, Mischel PS, Nelson SF, Elashoff R, Cloughesy TF. Bevacizumab and chemotherapy for recurrent glioblastoma: A single-institution experience. Neurology. 2009;72:1217-1222.

83. Mathieu V, De Neve N, Le Mercier M, Dewelle J, Gaussin JF, Dehoux M, Kiss R, Lefranc F. Combining bevacizumab with temozolomide increases the antitumor efficacy of temozolomide in a human glioblastoma orthotopic xenograft model. Neoplasia. 2008;10:1383-1392.

84. Carmeliet P, Jain RK. Principles and mechanisms of vessel normalization for cancer and other angiogenic diseases. Nat Rev Drug Discov. 2011;10:417-427.

85. Jain RK. Lessons from multidisciplinary translational trials on anti-angiogenic therapy of cancer. Nat Rev Cancer. 2008;8:309-316.

86. Batchelor TT, Sorensen AG, di Tomaso E, Zhang WT, Duda DG, Cohen KS, Kozak KR, Cahill DP, Chen PJ, Zhu M, Ancukiewicz M, Mrugala MM, Plotkin S, et al. Azd2171, a pan-vegf receptor tyrosine kinase inhibitor, normalizes tumor vasculature and alleviates edema in glioblastoma patients. Cancer Cell. 2007;11:83-95.

87. Kamoun WS, Ley CD, Farrar CT, Duyverman AM, Lahdenranta J, Lacorre DA, Batchelor TT, di Tomaso E, Duda DG, Munn LL, Fukumura D, Sorensen AG, Jain RK. Edema control by cediranib, a vascular endothelial growth factor receptor-targeted kinase inhibitor, prolongs survival despite persistent brain tumor growth in mice. J Clin Oncol. 2009;27:2542-2552.

88. Winkler F, Kozin SV, Tong RT, Chae SS, Booth MF, Garkavtsev I, Xu L, Hicklin DJ, Fukumura D, di Tomaso E, Munn LL, Jain RK. Kinetics of vascular normalization by vegfr2 blockade governs brain tumor response to radiation: Role of oxygenation, angiopoietin-1, and matrix metalloproteinases. Cancer Cell. 2004;6:553-563.

89. Timke C, Zieher H, Roth A, Hauser K, Lipson KE, Weber KJ, Debus J, Abdollahi A, Huber PE. Combination of vascular endothelial growth factor receptor/platelet-derived growth factor receptor inhibition markedly improves radiation tumor therapy Clin Cancer Res. 2008;14:22102219.

90. Kozin SV, Boucher Y, Hicklin DJ, Bohlen P, Jain RK, Suit HD. Vascular endothelial growth factor receptor-2-blocking antibody potentiates radiation-induced long-term control of human tumor xenografts. Cancer Res. 2001;61:39-44.

91. Liu J, Liao S, Huang Y, Samuel R, Shi T, Naxerova K, Huang P, Kamoun W, Jain RK, Fukumura D, Xu L. Pdgf-d improves drug delivery and efficacy via vascular normalization, but promotes lymphatic metastasis by activating cxcr4 in breast cancer. Clin Cancer Res. 2011;17:3638-3648.

92. Jayson GC, Parker GJ, Mullamitha S, Valle JW, Saunders M, Broughton L, Lawrance J, Carrington B, Roberts C, Issa B, Buckley DL, Cheung S, Davies K, et al. Blockade of platelet-derived growth factor receptor-beta by cdp860, a humanized, pegylated di-fab', leads to fluid accumulation and is associated with increased tumor vascularized volume. J Clin Oncol. 2005;23:973-981.

93. Erber R, Thurnher A, Katsen AD, Groth G, Kerger H, Hammes HP, Menger MD, Ullrich A, Vajkoczy P. Combined inhibition of vegf and pdgf signaling enforces tumor vessel regression by interfering with pericytemediated endothelial cell survival mechanisms. FASEB J. 2004;18:338-340.

94. Bergers G, Song S, Meyer-Morse N, Bergsland E, Hanahan D. Benefits of targeting both pericytes and endothelial cells in the tumor vasculature with kinase inhibitors. J Clin Invest. 2003;111:1287-1295.

95. Gerhardt H, Semb H. Pericytes: Gatekeepers in tumour cell metastasis? J Mol Med. (Berl) 2008;86:135-144.

96. Yonenaga Y, Mori A, Onodera H, Yasuda S, Oe H, Fujimoto A, Tachibana T, Imamura M. Absence of smooth muscle actin-positive pericyte coverage of tumor vessels correlates with hematogenous metastasis and prognosis of colorectal cancer patients. Oncology. 2005;69:159-166.

97. Pollack IF, Jakacki RI, Blaney SM, Hancock ML, Kieran MW, Phillips P, Kun LE, Friedman H, Packer R, Banerjee A, Geyer JR, Goldman S, Poussaint TY, et al. Phase i trial of imatinib in children with newly diagnosed brainstem and recurrent malignant gliomas: A pediatric brain tumor consortium report. Neuro Oncol. 2007;9:145-160.

98. Sandmann T, Bourgon R, Garcia J, Li C, Cloughesy T, Chinot OL, Wick W, Nishikawa R, Mason W, Henriksson R, Saran F, Lai A, Moore N, et al. Patients with proneural glioblastoma may derive overall survival benefit from the addition of bevacizumab to first-line radiotherapy and temozolomide: Retrospective analysis of the avaglio trial. J Clin Oncol. 2015

99. Rinne ML, Lee EQ, Nayak L, Norden AD, Beroukhim R, Wen PY, Reardon DA. Update on bevacizumab and other angiogenesis inhibitors for brain cancer. Expert Opin Emerg Drugs. 2013;18:137-153.

100. Norden AD, Young GS, Setayesh K, Muzikansky A, Klufas R, Ross GL, Ciampa AS, Ebbeling LG, Levy B, Drappatz J, Kesari S, Wen PY. Bevacizumab for recurrent malignant gliomas: Efficacy, toxicity, and patterns of recurrence. Neurology. 2008;70:779-787.

101. Miller K, Wang M, Gralow J, Dickler M, Cobleigh M, Perez EA, Shenkier T, Cella D, Davidson NE. Paclitaxel plus bevacizumab versus paclitaxel alone for metastatic breast cancer. N Engl J Med. 2007;357:2666-2676.

102. Hurwitz H, Fehrenbacher L, Novotny W, Cartwright T, Hainsworth J, Heim W, Berlin J, Baron A, Griffing 
S, Holmgren E, Ferrara N, Fyfe G, Rogers B, et al. Bevacizumab plus irinotecan, fluorouracil, and leucovorin for metastatic colorectal cancer.[see comment]. N Eng J Med. 2004;350:2335-2342.

103. Sandler A, Gray R, Perry MC, Brahmer J, Schiller JH, Dowlati A, Lilenbaum R, Johnson DH. Paclitaxelcarboplatin alone or with bevacizumab for non-small-cell lung cancer. N Engl J Med. 2006;355:2542-2550.

104. Manegold C. Bevacizumab for the treatment of advanced non-small-cell lung cancer. Expert Rev Anticancer Ther. 2008;8:689-699.

105. Bergers G, Hanahan D. Modes of resistance to antiangiogenic therapy. Nat Rev Cancer. 2008;8:592-603.

106. Verhoeff JJ, van Tellingen O, Claes A, Stalpers LJ, van Linde ME, Richel DJ, Leenders WP, van Furth WR. Concerns about anti-angiogenic treatment in patients with glioblastoma multiforme. BMC Cancer. 2009;9:444.

107. Field KM, Jordan JT, Wen PY, Rosenthal MA, Reardon DA. Bevacizumab and glioblastoma: Scientific review, newly reported updates, and ongoing controversies. Cancer. 2015;121:997-1007.

108. Batchelor TT, Reardon DA, de Groot JF, Wick W, Weller M. Antiangiogenic therapy for glioblastoma: Current status and future prospects. Clin Cancer Res. 2014;20:5612-5619.

109. Taphoorn MJ, Henriksson R, Bottomley A, Cloughesy T, Wick W, Mason WP, Saran F, Nishikawa R, Hilton M, Theodore-Oklota C, Ravelo A, Chinot OL. Healthrelated quality of life in a randomized phase iii study of bevacizumab, temozolomide, and radiotherapy in newly diagnosed glioblastoma. J Clin Oncol. 2015;33:2166-2175.

110. Lu-Emerson C, Duda DG, Emblem KE, Taylor JW, Gerstner ER, Loeffler JS, Batchelor TT, Jain RK. Lessons from anti-vascular endothelial growth factor and antivascular endothelial growth factor receptor trials in patients with glioblastoma. J Clin Oncol. 2015;33:1197-1213.

111. Taal W, Oosterkamp HM, Walenkamp AM, Dubbink HJ, Beerepoot LV, Hanse MC, Buter J, Honkoop AH, Boerman D, de Vos FY, Dinjens WN, Enting RH, Taphoorn MJ, et al. Single-agent bevacizumab or lomustine versus a combination of bevacizumab plus lomustine in patients with recurrent glioblastoma (belob trial): A randomised controlled phase 2 trial. Lancet Oncol. 2014;15:943-953.

112. Kovic B, Xie F. Economic evaluation of bevacizumab for the first-line treatment of newly diagnosed glioblastoma multiforme. J Clin Oncol. 2015;33:2296-2302.

113. Desjardins A. Neuro-oncology: What is the optimal use of bevacizumab in glioblastoma? Nat Rev Neurol. 2015;11:429-430.

114. Keunen O, Johansson M, Oudin A, Sanzey M, Rahim SA, Fack F, Thorsen F, Taxt T, Bartos M, Jirik R, Miletic H, Wang J, Stieber D, et al. Anti-vegf treatment reduces blood supply and increases tumor cell invasion in glioblastoma. Proc Natl Acad Sci U S A. 2011;108:3749-3754.

115. Segerstrom L, Fuchs D, Backman U, Holmquist K,
Christofferson R, Azarbayjani F. The anti-vegf antibody bevacizumab potently reduces the growth rate of high-risk neuroblastoma xenografts. Pediatr Res. 2006;60:576-581.

116. Paez-Ribes M, Allen E, Hudock J, Takeda T, Okuyama H, Vinals F, Inoue M, Bergers G, Hanahan D, Casanovas O. Antiangiogenic therapy elicits malignant progression of tumors to increased local invasion and distant metastasis. [see comment]. Cancer Cell. 2009;15:220-231.

117. Mancuso MR, Davis R, Norberg SM, O’Brien S, Sennino B, Nakahara T, Yao VJ, Inai T, Brooks P, Freimark B, Shalinsky DR, Hu-Lowe DD, McDonald DM. Rapid vascular regrowth in tumors after reversal of vegf inhibition. J Clin Invest. 2006;116:2610-2621.

118. Ebos JM, Lee CR, Cruz-Munoz W, Bjarnason GA, Christensen JG, Kerbel RS. Accelerated metastasis after short-term treatment with a potent inhibitor of tumor angiogenesis.[see comment]. Cancer Cell. 2009;15:232239.

119. Casanovas O, Hicklin DJ, Bergers G, Hanahan D. Drug resistance by evasion of antiangiogenic targeting of vegf signaling in late-stage pancreatic islet tumors: Cancer Cell. 2005, 8, pp 299-309.

120. Kioi M, Vogel H, Schultz G, Hoffman RM, Harsh GR, Brown JM. Inhibition of vasculogenesis, but not angiogenesis, prevents the recurrence of glioblastoma after irradiation in mice. J Clin Invest. 2010;120:694-705.

121. Dome B, Hendrix MJ, Paku S, Tovari J, Timar J. Alternative vascularization mechanisms in cancer: Pathology and therapeutic implications. Am J Pathol. 2007;170:1-15.

122. Folberg R, Hendrix MJ, Maniotis AJ. Vasculogenic mimicry and tumor angiogenesis. Am J Pathol. 2000;156:361-381.

123. Kirschmann DA, Seftor EA, Hardy KM, Seftor RE, Hendrix MJ. Molecular pathways: Vasculogenic mimicry in tumor cells: Diagnostic and therapeutic implications. Clin Cancer Res. 2012;18:2726-2732.

124. Liu XM, Zhang QP, Mu YG, Zhang XH, Sai K, Pang JC, $\mathrm{Ng} \mathrm{HK}$, Chen ZP. Clinical significance of vasculogenic mimicry in human gliomas. J Neurooncol. 2011;105:173179.

125. Cheng L, Huang Z, Zhou W, Wu Q, Donnola S, Liu JK, Fang X, Sloan AE, Mao Y, Lathia JD, Min W, McLendon RE, Rich JN, et al. Glioblastoma stem cells generate vascular pericytes to support vessel function and tumor growth. Cell. 2013;153:139-152. 